\title{
PHYSICS OF REACTOR SAFETY
}

Quarterly Report

April-June 1976 


\section{DISCLAIMER}

This report was prepared as an account of work sponsored by an agency of the United States Government. Neither the United States Government nor any agency Thereof, nor any of their employees, makes any warranty, express or implied, or assumes any legal liability or responsibility for the accuracy, completeness, or usefulness of any information, apparatus, product, or process disclosed, or represents that its use would not infringe privately owned rights. Reference herein to any specific commercial product, process, or service by trade name, trademark, manufacturer, or otherwise does not necessarily constitute or imply its endorsement, recommendation, or favoring by the United States Government or any agency thereof. The views and opinions of authors expressed herein do not necessarily state or reflect those of the United States Government or any agency thereof. 


\section{DISCLAIMER}

Portions of this document may be illegible in electronic image products. Images are produced from the best available original document. 
The facilities of Argonne National Laboratory are owned by the United States Government. Under the terms of a contract (W-31-109-Eng-38) between the U. S. Energy Research and Development Administration, Argonne Universities Association and The University of Chicago, the University employs the staff and operates the Laboratory in accordance with policies and programs formulated, approved and reviewed by the Association.

\section{MEMBERS OF ARGONNE UNIVERSITIES ASSOCIATION}

The University of Arizona Carnegie-Mellon University Case Western Reserve University

The University of Chicago

University of Cincinnati

Illinois Institute of Technology

University of Illinois

Indiana University

Iowa State University

The University of Iowa
Kansas State University The University of Kansas Loyola University Marquette University Michigan State University The University of Michigan University of Minnesota University of Missouri Northwestern University University of Notre Dame
The Ohio State University Ohio University The Pennsylvania State University Purdue University Saint Louis University Southern Illinois University The University of Texas at Austin Washington University Wayne State University The University of Wisconsin

\section{NOTICE}

This report was prepared as an account of work sponsored by the United States Government. Neither the United States nor the United States Energy Research and Development Administration, nor any of their employees, nor any of their contractors, subcontractors, or their employees, makes any warranty, express or implied, or assumes any legal liability or responsibility for the accuracy, completeness or usefulness of any information, apparatus, product or process disclosed, or represents that its use would not infringe privately-owned rights. Mention of commercial products, their manufacturers, or their suppliers in this publication does not imply or connote approval or disapproval of the product by Argonne National Laboratory or the U. S. Energy Research and Development Administration.

Printed in the United States of America

Available from

National Technical Information Service

U. S. Department of Commerce

5285 Port Royal Road

Springfield, Virginia 22161

Price: Printed Copy $\$ 4.00$; Microfiche $\$ 3.00$ 
Distribution Category: Advanced Reactor Safety Research-Fast Reactor's (NRC-7)

ANL - 76-114

ARGONNE NATIONAL LABORATORY

9700 South Cass Avenue

Argonne, Illinois 60439

PHYSICS OF REACTOR SAFETY

Quarterly Report

April-June 1976

Applied Physics Division

Work performed for the

Division of Reactor Safety Research

U. S. Nuclear Regulatory Commission

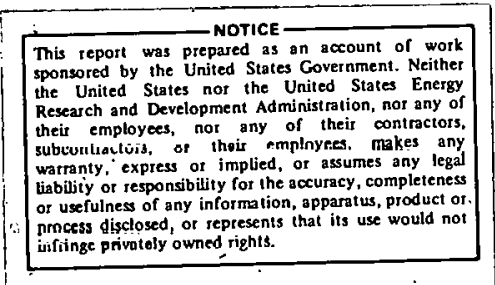

Previous reports in this series

ANL $-75-67$

April-June 1975

ANL-76-6 July-September 1975

ANL-76-13 October - December 1975

ANL-76-72 January-March 1976 
THIS PAGE

\section{WAS INTENTIONALLY LEFT BLANK}




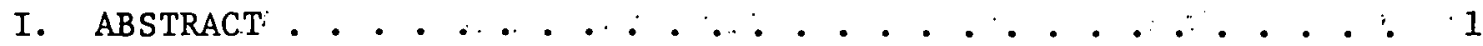

TECHNICAL COORDINATION - FAST REACTOR SAFETY ANALYSIS (A2015). 1

II. SUMMARY. . . . . . . . . . . . . . . . . . . . . . 1

III. STUDY OF BASIC PROBLEMS IN ACCIDENT ANALYSIS . . . . . . . . . 2

A. Initiating Condition Variations. . . . . . . . . . 2

1. Power and Material Worth Distribution in the FFTF-Grade Plutionium-Fueled Clinch River Breeder Reactor at the

- Beginning of Life . . . . . . . . . . . . 2

2. Comparison of Reactivity: Coefficients for the CRBR at End-of-Equilibrium Cycle (EOEC) as Computed with ENDF/BIII and ENDF/B-IV Based Cross Sections. . . . . . . 6

3. Comparison of Reactivity Coefficients for CRBR as Computed with the $\mathrm{R}-\mathrm{Z}$ Model and with the TwoDimensional Hexagonal Mesh Model. . . . . . . . 7

4. Effect of the Self-Overlap Correction on Doppler Effect Calculations.................. 8

B. Model Studies. . . . . . . . . . . . . . 9

1. Recriticality . . . . . . . . . . . . . . . 9

2. Autocatalysis from Bubble Collapse in Pools . . . . . 9

3. Heat Transfer Effects on Work Energy. . . . . . . . 9

4. Development of EPIC . . . . . . . . . . . . 14

IV. COORDINATION OF RSR SAFETY RESEARCH. . . . . . . . . . . . . 14

V. EVALUATION OF PROGRESS IN REACTOR SAFETY RESEARCH. . • • • • 15 MONTE CARLO ANALYSIS AND CRITICALS PROGRAM PLANNING FOR. SAFETY-RELATED CRITICALS (A2018) . . . . . . . . . . . 15

VI. MONTE CARLO ANALYSIS OF SAFETY-RELATED CRITICALS . . . . . 15 VII. PLANNING OF DEMO SAFETY RELATED EXPERIMENTS. . . . . . . . . 16 REFERENCES . . . . . . . . . . . . . . . . . . . . 23 


\section{LIST OF FIGURES}

No.

1. Subassembly Power Factors for the FFTF Plutonium Fueled Clinch River Breeder Reactor at the Beginning of Life. . . . . . . . . 3

2. Axial Distribution of Power in the FFTF-Plutonium Fueled Clinch River Breeder Reactor Core at the Beginning of Life. . . 4

3. Comparison of Void Worth Distributions in Core Between LWR-PuFueled and FFTF-Pu-Fueled CRBR at the Beginning of Life .' . . 5

4. Comparison of Steel Worth Distributions in Core Between LWR-PuFueled and FFTF-Pu-Fueled CRBR at the Beginning of Life . . . 5

5. Axial Distribution of Core Fuel Worth in Core in the FFTFPlutonium Fueled Clinch River Breeder Reactor at the Beginning of Life . . . . . . . . . . . . . . . . . 6

6. Particle Configurations . . . . . . . . . . . . 10

7. Heat Transfer Effects on Fuel Peak 'lemperature. . . . . . . 11

8. Heat Transfer Effects on Peak Pressure. . . . . . . . . . 12

9. Heat Transfer Effect on Work Potential. . . . . . . . . 13 


\section{LIST OF TABLES}

No.

$\underline{\text { Title }}$

$\underline{\text { Page }}$

I. Comparison of Power and Material Worths by Region Between

LWR-Pu-Fueled and FFTF-Pu-Fueled CRBR at the Beginning

of Life. . . . . . . . . . . . . . . . . . . 3

II. Comparison of Reactivity Coefficients for Full Core Height, by Channel, for CRBR at BOEC as Obtained from 2-D HexagonalMesh and $\mathrm{R}-\mathrm{Z}$ Perturbation Calculations, $\Delta \mathrm{k} / \mathrm{k}^{2} \times 10^{3}$. . . . 7

III. Comparison of Reactivity Coefficients about the Midplane, by Channel, for CRBR with Normal Sodium at EOEC as Obtained from $20 \mathrm{D}$ Hex and $\mathrm{R}-\mathrm{Z}$ Perturbation Calculations, $\Delta \mathrm{k} / \mathrm{k}^{2} \times 10^{4}$. 8

IV. Computed Eigenvalues . . . . . . . . . . . . . . . 16

V. Computed Eigenvalues for 1-D Spherical Model . . . . . . 16

VI. Sequence of Critical Assembly Core Configurations for Safety-Related Critical Experiments. . . . . . . . . . 17

VII. Outline of Measurements for Safety-Related Critical Experiments. . . . . . . . . . . . . . . . . . 21 


\title{
PHYSICS OF REACTOR SAFETY
}

Quarterly Report

April-June 1976

\section{ABSTRACT}

This quarterly progress report summarizes work done in Argonne National Laboratory's Applied Physics Division for the Division of Reactor Safety Research of the U.S. Nuclear Regulatory Commission during the months of April-June 1976. It includes reports on reactor safety research and technical coordination of the RSR safety analysis program by members of the Reactor Safety Appraisals Group, Monte Carlo analysis of safety-related critical assembly experiments by members of the Theoretical Fast Reactor Physics Group, and planning of DEMO safety-related critical experiments by members of the Zero Power Reactor (ZPR) Planning and Experiments Group.

\author{
TECHNICAL COORDINATION - FAST REACTOR \\ SAFETY ANALYSIS \\ (A2015)
}

\section{SUMMARY}

Comparisons of reactivity coefficients and power distributions for the BOL state of the CRBR revealed that the results obtained assuming LWR-grade plutonium generally differed little from those obtained assuming FFTF-grade plutonium. A major part of the difference in reactivity worths measured in dollars arises from a $9 \%$ difference in $B$ eff calculated for the two cases.

Comparison of reactivity coefficients for the EOEC state of the CRBR using ENDF/B Version III and Version IV indicated generally minor differences, except that the positive sodium void effect over the core increased by 20 to $25 \%$.

Comparison of reactivity coefficients for the CRBR using $R-Z$ and twodimensional hexagonal mesh calculations indicated that the most significant errors in the $\mathrm{R}-\mathrm{Z}$ model were in the sodium and steel worths. Errors in the sodium worth in a considerable part of the core were in the range of $20-40 \%$ for the BOEC case. For the EOEC case, withdrawal of control rnds resulted in smaller flux variations and therefore smaller errors in the $\mathrm{R}-\mathrm{Z}$ model.

It was determined that the net effect of resonance self-overlap on the CRBR Doppler effect was about $8 \%$, so that uncertainty in treatment of this effect should be less than $8 \%$.

A new FX2-POOL computational path has been written to calculate the polential autocatalytic effect of hubhle collapse in a boiling fuelsteel pool. 
POOL and FX2-POOL were modified to calculate the work energy available from fuel and steel at any time during an HCDA. The effect of fuel to steel heat transfer has been found to have a negligible effect on the total energy release in an HCDA, but can have an important effect on work energy on a time scale of 20 to $30 \mathrm{~ms}$. Fuel-steel heat transfer should reduce the work energy as the steel would have to have an initial temperature of more than $2500^{\circ} \mathrm{K}$ for the work energy to be increased.

Programming of the multinode failure option in the EPIC fuel-coolant interaction code and of capability for a dealing with a partially voided channel has been completed. The first version of the code is now in a final testing phase to be sure that all options operate successfully.

It is hoped to have a preliminary plan for validation of the SIMMER and HAARM codes by the end of calendar year 1976. Strong areas of mutual benefit have been identified between the HAARM experimental effort and the SIMMER analysis.

III. STUDY OF BASIC PROBLEMS IN ACCIDENT ANALYSIS

A. Initiating Condition Variations.

1. Power and Material Worth Distribution in the FFTF-Grade PlutoniumFueled Clinch River Breeder Reactor at the Beginning of Life (Kalimullah and H. H. Humme I)

We have summarized here the results of some calculations of power, sodium void, steel and core fuel worth distributions for the FFTF-grade plutonium fueled $C R B R$ at $B O L$, and have compared theec reaults with those for the LWR-grade plutonium fueled CRBR at BOL reported earlier. 1. The isotoplc composition of the FFTF-grade plutonium, $238 \mathrm{Pu} / 239 \mathrm{Pu} / 240 \mathrm{Pu} / 241 \mathrm{Pu} / 242 \mathrm{Pu}$, is $0.0 / 86.4 / 11.7 / 1.7 / 0.2 \mathrm{w} / \mathrm{o}$ compared to $1.0 / 67.3 / 19.2 / 10.1 / 2.4 \mathrm{w} / \mathrm{o}$ of the LWR discharge grade plutonium. With the FFTF-grade plutionium the required enrichments of the inner and outer core regions are 17.7 and $25.6 \mathrm{w} / \mathrm{o}$ $\mathrm{Pu} /(\mathrm{U}+\mathrm{Pu})$ compared to 18.7 and $27.1 \mathrm{w} / \mathrm{o} \mathrm{Pu} /(\mathrm{U}+\mathrm{Pu})$ for the LWR-grade plutonium fuel. The fill-height hot full power $R-Z$ model used is based on $\left(\mathrm{U}, \mathrm{Pu} \mathrm{O}_{2}\right.$ masses reported in the $\mathrm{PSAR}^{2}$ (Table 4.3-32) and dimensions and volume fractions reported in Table $\mathrm{D} 4-1$, with the sodium density varying axially as a function of its steady state temperature calculated by the SAS Code. ${ }^{3}$ Control rod insertions, cross-sections and other details of the calculations are the same as those used in the case of the LWR-grade plutonium. Table I summarizes the regional totals of power, sodium void, steel and core fuel worths both for the FFTF-grade and the LWR-grade plutonium fuels, the method of analysis being alike in each case. Figure 1 shows the subassembly power factors obtained from a 2-D triangular mesh diffusion theory calculation with the control rod and the 6 rods at flats of row 7 fully inserted. Figure 2 shows the axial distribution of power in all the rows of the core obtained from a 2-D R-Z diffusion theory calculation with partially inserted control rods, and with the fuel assumed at a uniform temperature of $1100^{\circ} \mathrm{K}$. Comparison of regional power totals, subassembly power factors, subassembly peak-to-average power density ratios and axial power profiles between the FFTF-grade and the LWR-grade plutonium fuels shows that the power distribution remains essentially unchanged. 
TABLE I. Comparison of Power and Material Worths by Region Between LWR-Pu-Fueled and FFTF-Pu-Fueled CRBR at the Beginning of Life

\begin{tabular}{|c|c|c|c|c|c|c|c|}
\hline Power or Worth & $\begin{array}{l}\text { Fuel } \\
\text { Type }\end{array}$ & $\begin{array}{l}\text { Inner } \\
\text { Core }\end{array}$ & $\begin{array}{l}\text { Outer } \\
\text { Core }\end{array}$ & $\begin{array}{l}\text { Lower } \\
\text { Blanket. }\end{array}$ & $\begin{array}{l}\text { Upper } \\
\text { Blanket }\end{array}$ & $\begin{array}{l}\text { Radial } \\
\text { Blanket }\end{array}$ & Total \\
\hline Power, MWt & $\begin{array}{l}\text { FFTF } \\
\text { LWR }\end{array}$ & $\begin{array}{l}531.5 \\
531.2\end{array}$ & $\begin{array}{l}404.5 \\
404.8\end{array}$ & $\begin{array}{l}7.7 \\
7.7\end{array}$ & $\begin{array}{l}6.3 \\
6.3\end{array}$ & $\begin{array}{l}25.0 \\
25.0\end{array}$ & $\begin{array}{l}975.0 \\
975.0\end{array}$ \\
\hline $\begin{array}{l}\text { Sodium void worth, } \\
10^{3} \Delta \mathrm{k} / \mathrm{k}\end{array}$ & $\begin{array}{l}\text { FFTF } \\
\text { LWR }\end{array}$ & $\begin{array}{l}11.83 \\
10.93\end{array}$ & $\begin{array}{l}-2.05 \\
-2.37\end{array}$ & $\begin{array}{l}-1.03 \\
-1.06\end{array}$ & $\begin{array}{l}-0.638 \\
-0.656\end{array}$ & $\begin{array}{l}-1.49 \\
-1.51\end{array}$ & $\begin{array}{l}6.63 \\
5.34\end{array}$ \\
\hline $\begin{array}{l}\text { Worth of half steel, } \\
10^{3} \Delta \mathrm{k} / \mathrm{k}\end{array}$ & $\begin{array}{l}\text { FFTF } \\
\text { LWR }\end{array}$ & $\begin{array}{l}-18.61 \\
-18.29\end{array}$ & $\begin{array}{l}-1.15 \\
-1.05\end{array}$ & $\begin{array}{l}1.18 \\
1.18\end{array}$ & $\begin{array}{l}0.829 \\
0.832\end{array}$ & $\begin{array}{l}2.08 \\
2.09\end{array}$ & $\begin{array}{l}-15.68 \\
-15.23\end{array}$ \\
\hline $\begin{array}{l}\text { Core fuel worth, } \\
10^{3} \Delta \mathrm{k} / \mathrm{k}\end{array}$ & $\begin{array}{l}\text { FFTF } \\
\text { LWR }\end{array}$ & $\begin{array}{l}263.8 \\
262.8\end{array}$ & $\begin{array}{l}187.5 \\
187.8\end{array}$ & $\begin{array}{l}39.58 \\
39.91\end{array}$ & $\begin{array}{l}29.64 \\
29.83\end{array}$ & $\begin{array}{l}5.92^{a} \\
5.94^{a}\end{array}$ & $\begin{array}{l}526.5 \\
526.3\end{array}$ \\
\hline
\end{tabular}

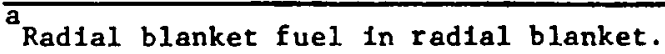

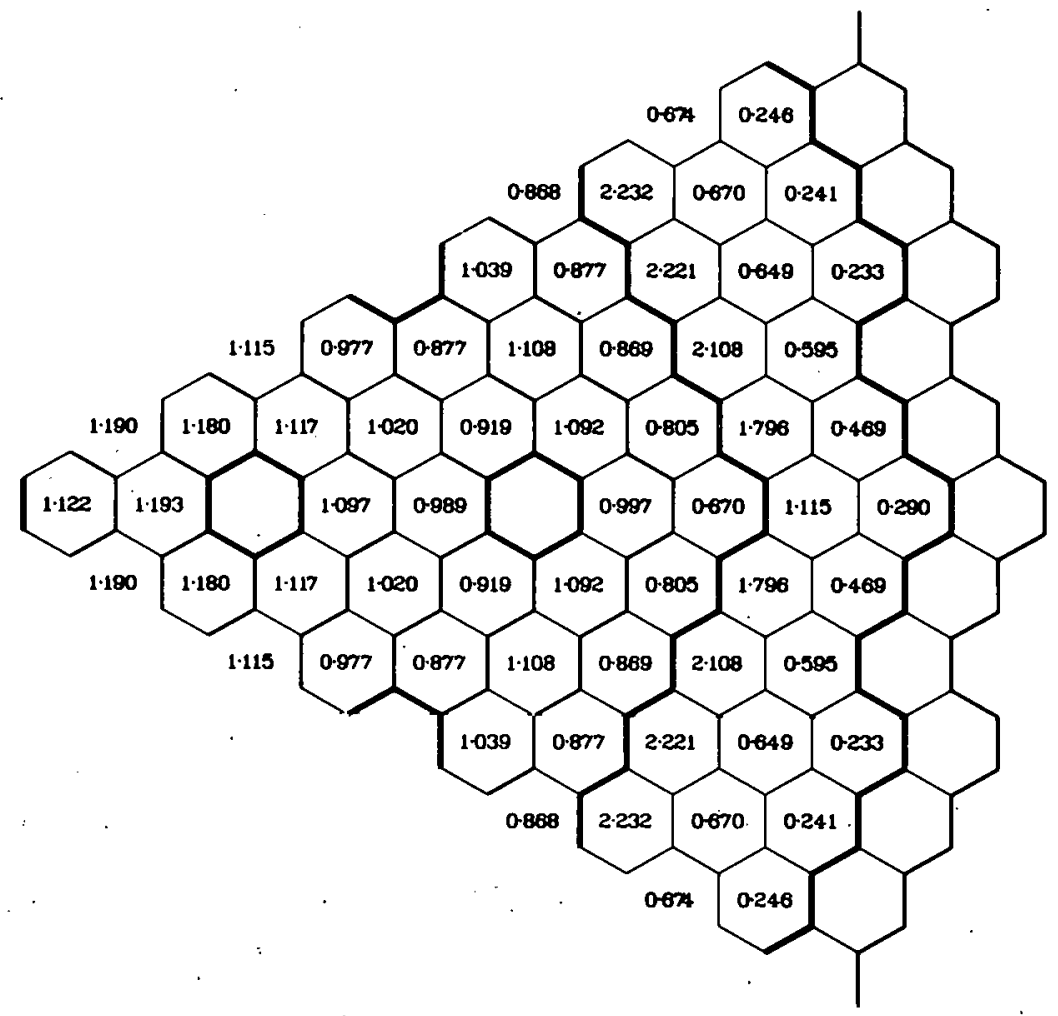

Fig. 1. Subassembly Power Factors for the FFTF Plutonium Fueled $\mathrm{Cl}$ inch River Breeder Reactor at the Beginning of Life. ANL $\mathrm{Neg}$. No. $116-76-255$. 


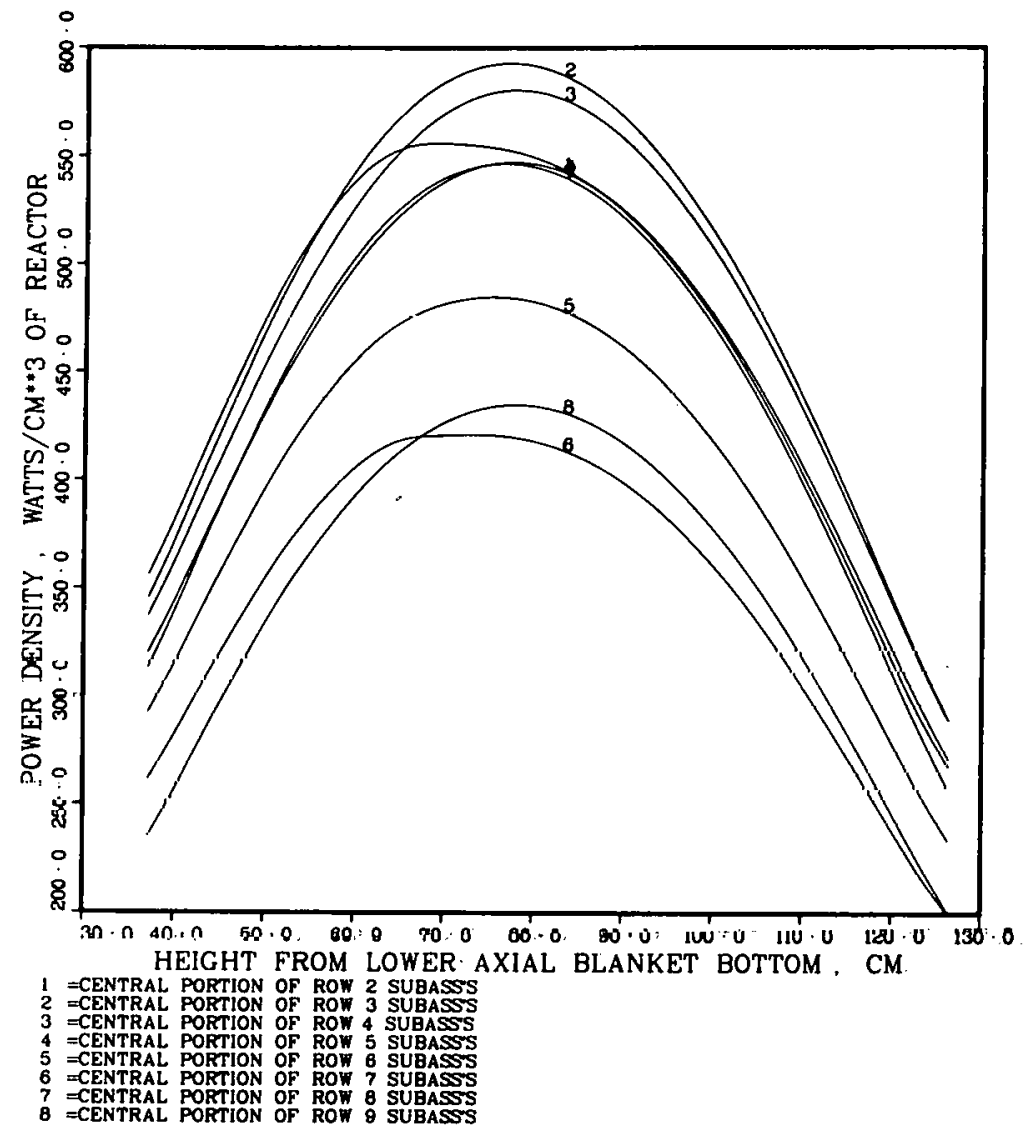

Fig. 2, Axjal Distribution of Power in the FFTF-Plutonium Fueled Clinch River Breeder Reactor Core at the Beginning of Life. ANL Neg.

No. $116-76-252$.

'Lhe sodium void and steel worth distributions have been computed by 2-D R-Z diffusion theory linearized leakage perturbations using the real and adjoint fluxes generated in the normal reactor at a uniform fuel temperature of $1100^{\circ} \mathrm{K}$. Figures 3 and 4 show comparisons of typical dxial distributinns in core of sodium void and steel worths for the FFTF-grade and the LWR-grade plutonium fuels (obtained by precisely the same method of analysis). In the blanket regions the comparisons are even closer than those in the core regions both for the sodium void and the steel worth distributions. When converted into dollars, (total effective delayed neutron fraction is 0.00335 using FFTF fuel compared to 0.0036 ' using LWR fuel as reported in the PSAR, ${ }^{2}$ Table 4.3-33) the inner core sodium void worth with the FFTF-plutonium fuel is found about $18 \%$ larger than that with the LWR-plutonium fuel, whereas the corresponding comparison reported in the PSAR, 2 Table 4.3-35 shows an increase of about $24 \%$. A similar comparison of the inner core steel worth shows an increase in magnitude of a little less than $11 \%$ only. Figure 5 shows a typical axial distribution of core fuel worth in all the rows of the core computed by 2-D $\mathrm{R}-\mathrm{Z}$ diffusion theory linearized leakage perturbation using the real and adjoint fluxes generated in the core-and-blanket-voided reactor at a uniform fuel temperature of $1100^{\circ} \mathrm{K}$. Comparison of fuel worth distributions between the FFTF-plutonium and the LWR-plutonium fueled CRBR shows that these are 


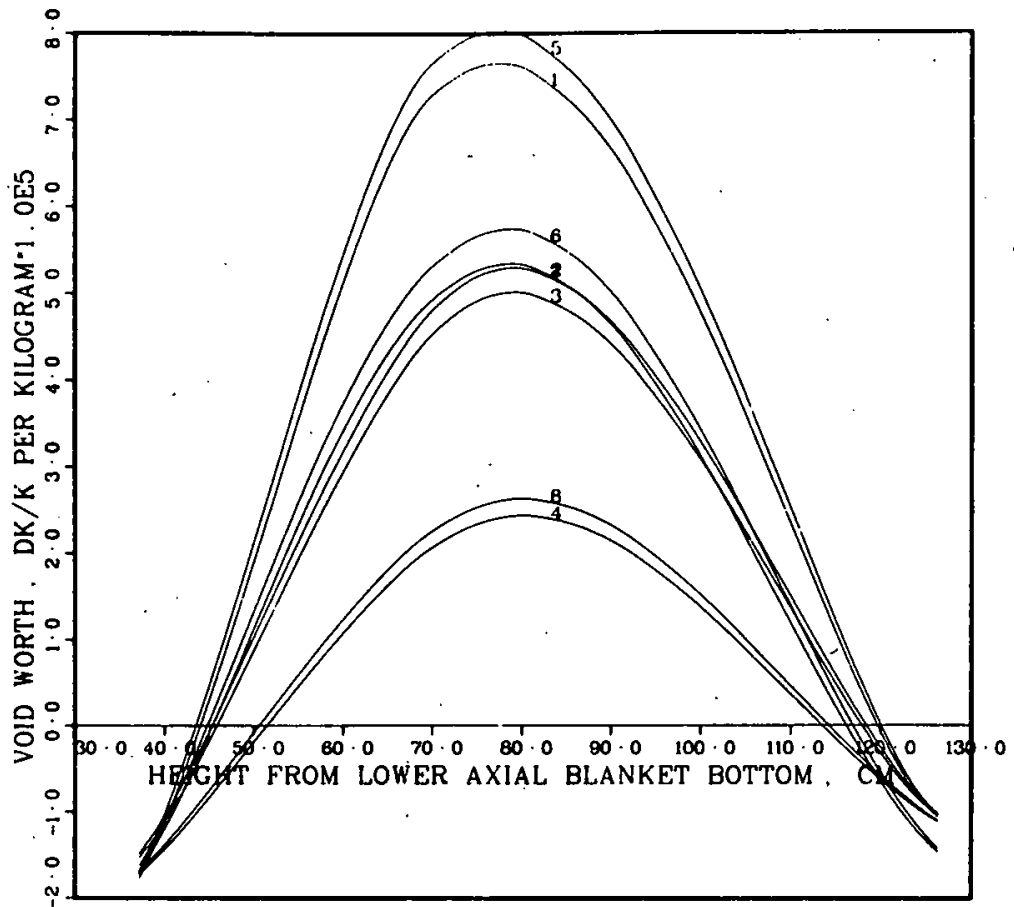

Fig. 3

Comparison of Void Worth Distributions in Core Between LWR-Pu-Fueled and FFTF-Pu-Fueled CRBR at the Beginning of Life. ANL Neg. No. 116-76-253.

1 = WWR-PU FUEL. CENTRAL PORTION OF ROW 2 SUBASSS

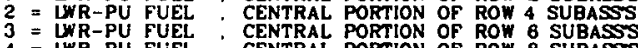

$4=$ LWR-PU FUEL: CENTRAL PORTION OF ROW B SUBASSS

$5=$ FFTF-PU FUEL. RADIAL POSITION SAME AS 1

$7=$ FFTF-PU FUEL: RADIAL POSITION SAME AS 3
$\mathbf{8}=$ FFTF..PU FUEL : RADIAL POSITION SAME AS 4

F.ig, 4

Comparison of Steel Worth Distributions in Core Between LWR-Pu-Fueled and FFTF-Pu-Fueled CRBR at the Beginning of Life. ANL Neg. No. 116-76-254.

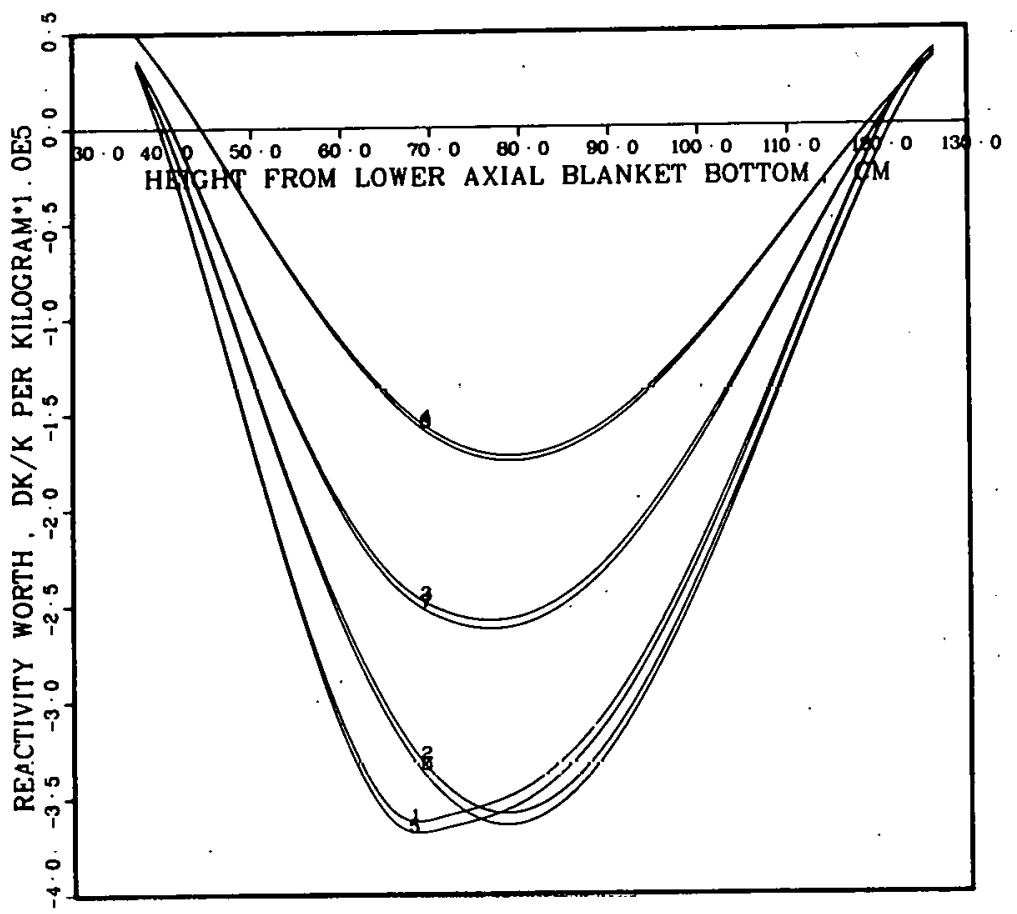

1 = UMR-PU FUEL . CENTRAL PORTION OF ROW 2 SUBASSS

$2=$ W T-PU FUEL : CENTRAL PORTION OF ROW 4 SUBASSS

$3=$ WR-PU FUEL : CENTRAL PORTION OF ROW 6 SUBASSS

$4=$ FFTF-PU FUEL : RADIAL POSITION SAME AS 1

$7=$ FPTP-PU FUEL: RADIAL POSITION SAME AS 3 . 


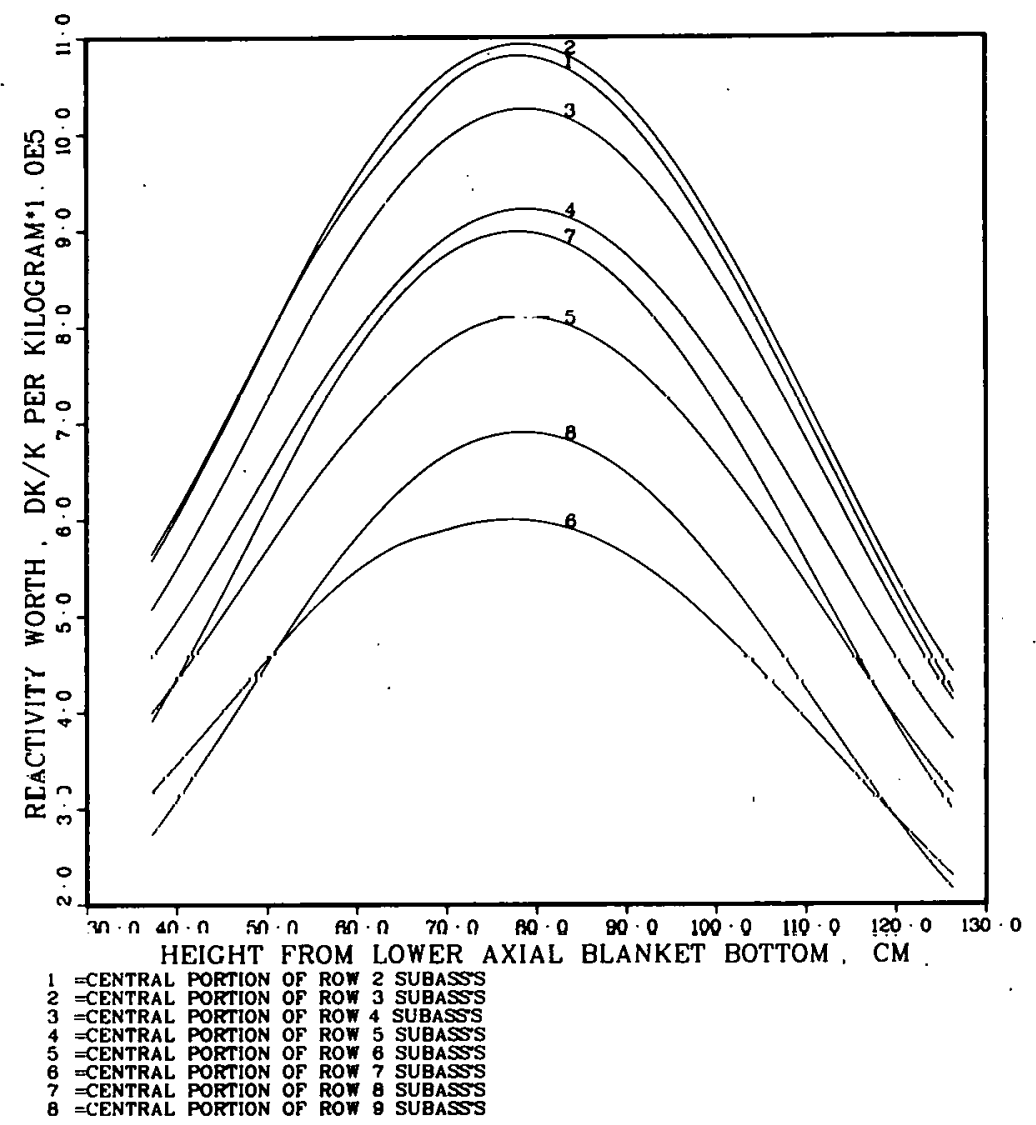

Fig. 5

Axial Distribution of Core Fuel Worth in Core in the FFTF-Plutonium Fueled Clinch River Breeder Reactor at the Beginning of Life. $\Lambda \mathrm{NL} \mathrm{Neg}$. No. $116-76-251$.

essentially the same in units of $\Delta \mathrm{k} / \mathrm{k}$ per kilogram. It should be pointed out that the FFTF-plutonium fuel is about $9 \%$ higher in specific reactivity worth than the LWR-plutonium fuel because of the difference in the total delayed neutron fraction.

2. Comparison of Reactivity Coefficients for the CRBR at End-ofEquilibrium Cycle (EOEC) as Computed with ENDF/B-III and ENDF/B-IV Based Cross Sections (P. H. Kier)

To provide information on the sens1tivity of calculated reactivity coefficients to basic neutron data and procedures for processing these data into broad group cross section, reactivity coefficient computed for EOEC conditions with use of a cross section library based on ENDF/B-III data ${ }^{4}$ have been recalculated with a new library based on ENDF/B-IV data. This new library has several refinements not usually made. The temperature dependence of scattering cross sections is accounted for, the constituents of stainless steel are treated as resonant materials, and integral transport theory rather than the narrow resonance approximation is used to compute resonance absorption in the resolved resonance energy range.

The rceults of this study will now bc summarized. The use of the new library results in negligible changes in core fuel worth and power distributions. It did result, however, in significant increases in sodium void worths of about $30 \%$ (20 to $25 \%$ over the core) and increases in steel worth of about $5 \%$. There was also an increase in the fuel Doppler coefficient of between 1 and $5 \%$. Since the constituents of steel were treated as resonant materials in generating the new library, they have temperature-dependent cross sections and 
their contribution to the Doppler effect can be calculated. With the assumption that the change in temperature in the steel is the same as in the fuel, for the compositions in CRBR at EOEC, including the Doppler effect in the constituents of steel would increase the overall Doppler coefficient by about $10 \%$.

3. Comparison of Reactivity Coefficients for CRBR as Computed with the $\mathrm{R}-\mathrm{Z}$ Model and with the Two-Dimensional Hexagonal Mesh Model (P. H. Kier)

It is of interest to comparison reactivity coefficients as computed with two-dimensional $\mathrm{R}-\mathrm{Z}$ and hexagonal-mesh perturbation theory models to gain insight into the uncertainties introduced into the calculation of these quantities from attempting to represent a three-dimensional system with two-dimensional models.

For Beginning-of-Equilibrium Cycle (BOEC) conditions for which there are partly inserted control rods, reactivity coefficients over the entire height of the core were compared for the reactor at $1100^{\circ} \mathrm{K}$ and with sodium unvoided. The results of this comparison are given by channel in Table II. From the table it is seen that the Doppler worth and core fuel worth are relatively insensitive to the two-dimensional representation of the system. For the steel worth, the discrepancies are larger and for the sodium void worth the discrepancies are sizable for several channels. For the sodium void worth the net reactivity as computed with first order perturbation theory was decomposed into components. Genera1ly, the major contributions to the discrepancy arose from differences in two components: net scattering and radial leakage. There were large relative differences in the radial leakage component which indicates that local flux gradients are not well represented in two-dimensional models. Although the relative differences in the net scattering component are smaller, the magnitude of the component is larger than the radial leakage component and generally has a larger contribution to the sodium worth discrepancy.

TABLE-II. Comparison of Reactivity Coefficlents for Full Core Height, by Channel, for CRBR at BOEC as Obtalned from 2-D Hexagonal-Mesh and R-Z Perturbation Calculations, $\Delta \mathrm{k} / \mathrm{k}^{2} \times 10^{3}$

\begin{tabular}{|c|c|c|c|c|c|c|c|c|c|}
\hline \multirow[b]{2}{*}{ Channel } & \multirow[b]{2}{*}{ Subass'y. I.D. } & \multicolumn{2}{|c|}{ Sodium Void } & \multicolumn{2}{|c|}{ Steel Removal } & \multicolumn{2}{|c|}{ Doppler Worth } & \multirow{2}{*}{$\begin{array}{l}\text { Core Fuel } \\
\text { Hex }\end{array}$} & \multirow{2}{*}{$\begin{array}{l}1 \text { Worth } \\
R-Z\end{array}$} \\
\hline & & Hex & $\mathrm{R}-\mathrm{z}$ & Hex & $\mathrm{R}-\mathrm{z}$ & Hex & $R-z$ & & \\
\hline 1 & 1,7 & 1.758 & 1.849 & 5.423 & 5.748 & -0.3917 & -0.4399 & 42.11 & 42.84 \\
\hline 2 & 3,6 & 1.684 & 1.774 & 5.482 & 5.656 & -0.3886 & -0.4257 & 32.74 & 32.80 \\
\hline 3 & $2,10,15$ & 2.271 & 2.636 & 7.147 & 7.987 & -0.4867 & -0.5465 & 36.70 & 36.18 \\
\hline 4 & $5,8,16$ & 1.647 & 2.252 & 5.221 & 5.992 & -0.3824 & -0.3554 & 37.10 & 36.74 \\
\hline 5 & $4,9,11,14$ & 1.999 & 2.765 & 5.669 & 7.086 & -0.4541 & -0.4324 & 57.82 & 57.54 \\
\hline 6 & $12,13,17$ & 1.586 & 1.798 & 4.307 & $4.11 y$ & -0.2479 & -0.2577 & 26.64 & 26.64 \\
\hline 7 & 19,22 & 0.461 & 0.244 & 1.825 & 1.230 & -0.1040 & -0.1015 & 24.68 & 23.40 \\
\hline 8 & $18,24,28,31,68$ & 0.299 & 0.573 & 3.080 & 3.662 & -0.2102 & -0.2436 & 61.56 & 68.89 \\
\hline 9. & $20,23,32$ & 0.274 & 0.471 & 1.661 & 2.338 & -0.1386 & -0.1552 & 29.11 & 31.34 \\
\hline 20 & $21,25,26,27,29,30$ & -0.643 & -0.585 & 0.053 & 0.117 & -0.2474 & -0.2672 & 49.93 & 52.16 \\
\hline
\end{tabular}


For End-of-Equilibrium Cycle (EOEC) conditions, for which all control rods were withdrawn from the core, reactivity coefficients were compared for a height of $5.6 \mathrm{~cm}$ centered about the core midplane. This comparison gives an indication of the errors introduced by azimuthal smearing of subassemblies with different compositions. For this case, the agreement between the $R-Z$ and the hexagonal-mesh calculations were excellent for the Doppler worth and the core fuel worth and were generally significantly better for the sodium void worth and steel worth than for the BOEC case as can be seen from Table III. The significant1y better agreement for the EOEC case was to be expected because the BOEC case presented a far more severe test of two-dimensional models.

TABLE III. Comparison of Reactivity Coefficlents about the Midplane, by Channel, for CRBR w1th Normal Sodium at EOEC as Obtained from $20 \mathrm{D}$ Hex and R-z Perturbation Calculations, $\Delta k / k^{2} \times 10^{4}$

\begin{tabular}{|c|c|c|c|c|c|c|c|c|c|}
\hline \multirow[b]{2}{*}{ Channel } & \multirow{2}{*}{ Subass'y. I.D. } & \multicolumn{2}{|c|}{ Sodiun Yold } & \multicolumn{2}{|c|}{ Sterel. Remova] } & \multicolumn{2}{|c|}{ Doppter Worth } & \multirow{2}{*}{$\begin{array}{l}\text { Core Fuol. } \\
\text { Hex }\end{array}$} & \multirow{2}{*}{$\begin{array}{l}\text { Worth } \\
\text { R-z }\end{array}$} \\
\hline & & Hex & $\mathrm{R}-\mathrm{z}$ & Hex & $\mathrm{R}-\mathrm{Z}$ & Hex & $R-Z$ & & \\
\hline 1 & 1,7 & 2.171 & 2.317 & 5.95 .3 & 6.196 & $-n .1716$ & -0.7719 & 24.25 & 25,34 \\
\hline 2 & $2,3,6$ & 3.420 & 3.605 & 8.938 & 9.194 & -0.4283 & -0.4221 & $26 \cdot 51$ & 27.38 \\
\hline 3 & $4,11,14$ & 2.631 & 2.658 & 7.190 & 7.278 & -0.4040 & -0.3814 & 31.32 & 31.63 \\
\hline 4 & $8,1 \cap, 15,13,16$ & 1.816 & 5.169 & 12,005 & $13: 483$ & 0.6063 & $=0.6205$ & 30.20 & 39.61 \\
\hline 5 & 18,24 & 0.788 & 1.105 & 28.58 & 3.455 & -0.1598 & -0.1661 & 26.64 & 28.80 \\
\hline 6 & 19,22 & 0.438 & 0.521 & 1.758 & 1.930 & -0.1151 & -0.1144 & 18.68 & 19.36 \\
\hline 7 & $5,9,21,26,68$ & 2.283 & 2.494 & 7.190 & 7.659 & -0.4280 & -0.4397 & 43.12 & 44.54 \\
\hline 8 & $20,23,25$ & 0.619 & 0.714 & 2.512 & 2.713 & -0.1654 & -0.1615 & 25.29 & 25.38 \\
\hline 9 & $12,17,32$ & 1.557 & ]. 496 & 1.652 & $4,6 \wedge 1$ & -0.2134 & -0.2392 & 20.22 & 20.76 \\
\hline 10 & $27,28,29,30,31$ & -0.414 & -0.752 & 0.946 & -0.563 & -0.1802 & -0.1732 & 34.56 & 35.39 \\
\hline
\end{tabular}

4. Elfecl uf Lhe Self-Overlap Correction on Doppler Effect Colculaelong (T. II. ICleir)

As part of our continuing program to determine uncertainties in the computation of reactivity coefficients, a study was made of the effect of the self-overlap correction to resonance cross sections in the unresolved resonance energy rangè on computed Joppler reactivities. Lhanges in the capture cross sections of ${ }^{238} \mathrm{U}$ and in the capture, fission and nu-fission cross sections of $2{ }^{39} \mathrm{Pu}$ between 1100 and $4400^{\circ} \mathrm{K}$ were obtained both including and neglecting the self-overlap correction. These two sets of Doppler difference cross sections were input as perturbations for a simplified, one-dimensional representation of the unvoided CRBR. For ${ }^{2}{ }^{38} \mathrm{U}$, neglect of the self-overlap correction resulted in an increase in the contribution from the unresolved resonance energy range of about 25\%. However, as only about a quarter of the $238 \mathrm{U}$ Doppler effect comes from the unresolved resonance energy range, the net effect was about $8 \%$. For ${ }^{2}{ }^{39} \mathrm{Pu}$, whose unresolved resonance energy $\mathrm{r}$ ange extends down to a few hundred electron-volts, neglect of the self-overlap correction results in an increase in the Doppler effect of about $25 \%$; however, the contribution to the overall Doppler effect from ${ }^{239} \mathrm{Pu}$ is only a few percent of ${ }^{238} \mathrm{U}$ and of opposite algebraic sign. Thus it appears that any uncertainty introduced into the calculation of the Doppler effect from the treatment of the self-overlap effect would be less than $8 \%$. 


\section{B. Model Studies}

\section{Recriticality (P. B. Abramson)}

We are continuing work on a combined compressible/incompressible flow algorithm in order to be able to follow long time (tenths of seconds) flows in pulsed pools.

We are, at this point, able to examine the influence of local pressure pulses on pools which are near $\mathrm{k}=1$ to study the parametric impacts on energy deposition. A new FX2-POOL calculational path will have to be written which allows POOL to cal1 FX2 rather than vice versa as in the current FX2-POOL version. When this is accomplished, the cost of these proposed parametric studies can be reduced by as much as an order of magnitude by performing the more expensive neutronics calculations only when they are needed. We will proceed with examination of such phenomena when the new path is written.

\section{Autocatalysis from Bubble Collapse in Pools}

(P. B. Abramson and T. A. Daly)

Using Monte Carlo calculations of the effect of bubble size and void fraction on diffusion coefficients performed by R. Lell and E. Gelbard, we have written a new FX2-POOL path which can calculate the autocatalytic effect of decreased neutronic streaming due to bubble collapse in a boiling pool undergoing rapid heating (and therefore liquid phase expansion) due to a prompt critical excursion. This code is now in the debugging stage, and calculations should be made in the next quarter.

3. Heat Transfer Effects on Work Energy (P. B. Abramson)

POOL and FX2-POOL were modified to calculate the work energy available (thermodynamic potential energy) from either fuel or steel or both, at any point along the time development of the HCDA. This was accomplished by incorporating into these codes the VENUS adiabatic expansion models used in the assessment of work energy by VENUS. Using the 1000 MW(e) Reactor calculation which we used to compare VENUS and FX2-POOL results, ${ }^{5}$ calculations of the importance of fuel to steel heat transfer both during the prompt burst and in the 20 to $30 \mathrm{~ms}$ following the prompt burst. It was found that the fuel to steel heat transfer has essentially no role during the prompt burst (for these large ramp rate calculations of $\$ 50 /$ second and up). However, during the time it takes for a vapor bubble to grow to the size of the original active core (20 or $30 \mathrm{~ms}$ ), we find that fuel to steel heat transfer can play a significant role.

If the fuel to steel heat transfer is represented parametrically by

$$
\dot{Q}=\operatorname{CA}\left(\mathrm{T}_{\text {fuel }}-\mathrm{T}_{\text {steel }}\right)+\operatorname{A\sigma \varepsilon }\left(\mathrm{T}_{\text {fuel }}^{4}-\mathrm{T}_{\text {steel }}^{4}\right)
$$

then variation of $C$ and $A$ over a reasonable range of values can produce significant changes in the core materials behavior. Figure 6 shows the core marker particle distributions at the end of the prompt burst (6+ms) and at the time the core materials reach the blankets $(30+\mathrm{ms})$. 
$\operatorname{TME}($ SECONDS $)=0,006360$

$\operatorname{TME}($ SECONOS $)=0,009860$

PARTICLE DISTRIBUTION FROM HCDA

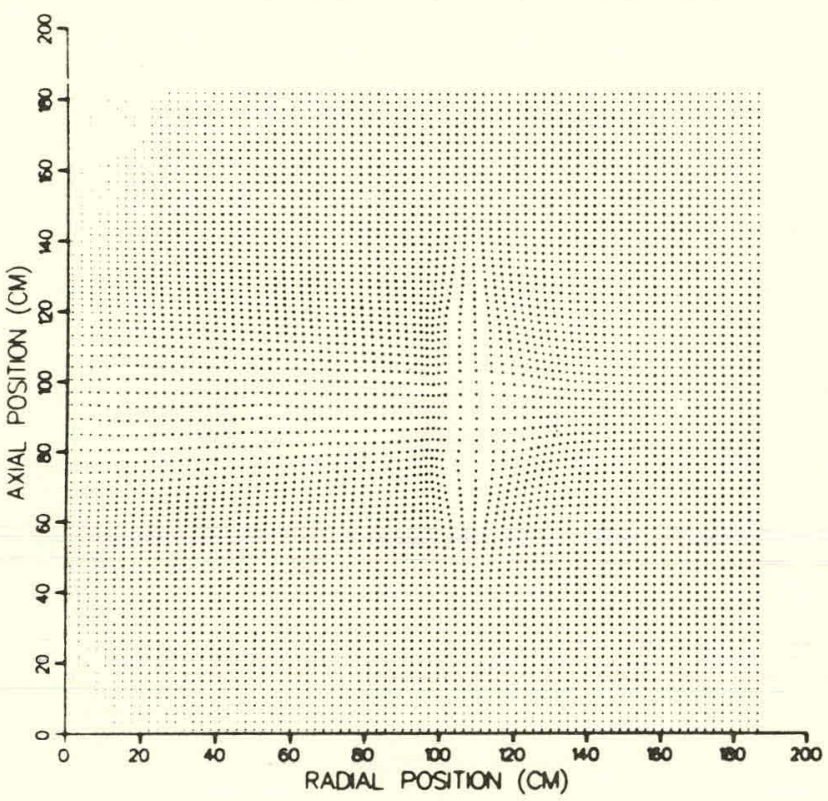

PARTICLE DISTRIBUTION FROM HCDA

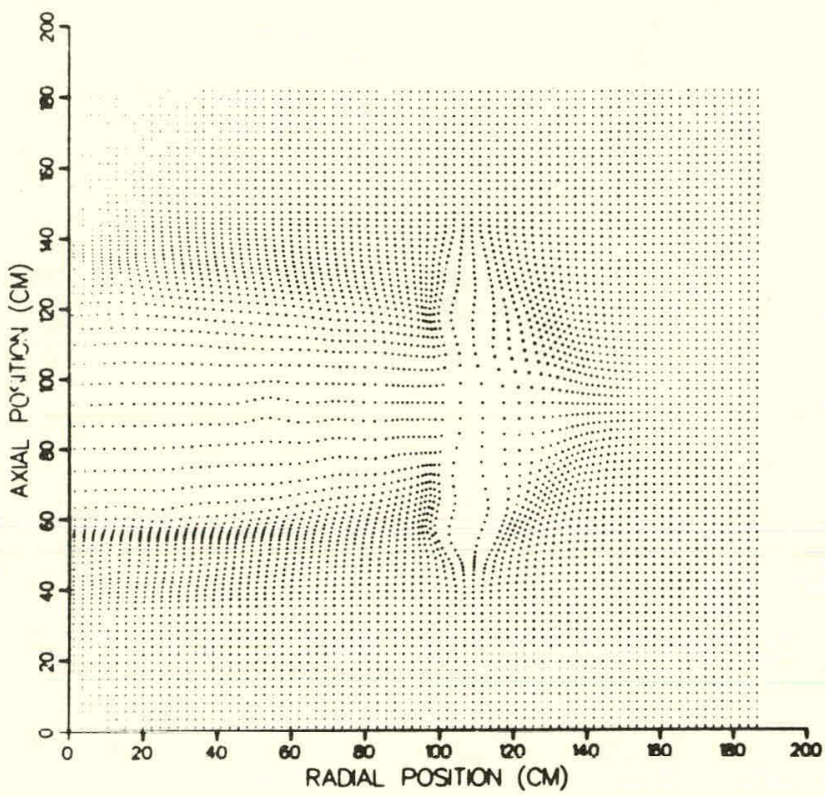

TME(SECONOS) $=0-020360$

$\operatorname{TME}(S E C O N D S)=0-030360$

PARTICLE DISTRIBUTION FROM HCDA

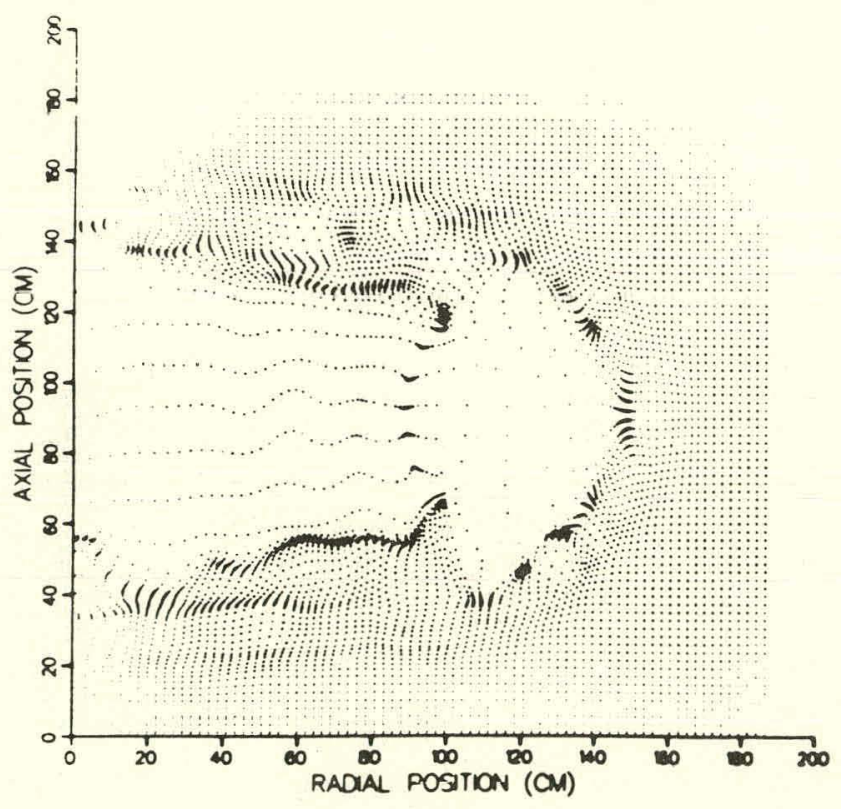

PARTICLE DISTRIBUTION FROM HCDA

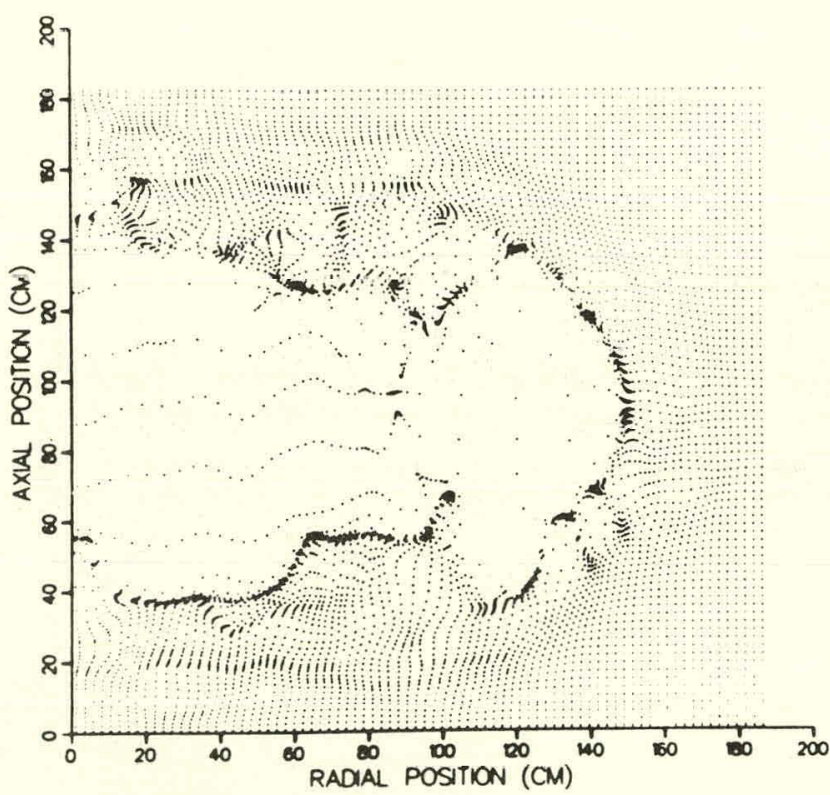

Fig. 6. Particle Configurations. $\Lambda N L$ Ncg. No. 116-76, 125. 
Figure 7 shows the influence of variation of $C$ and $A$ on the peak fuel temperature during that period, while Fig. 8 shows the same effects on peak pressure.

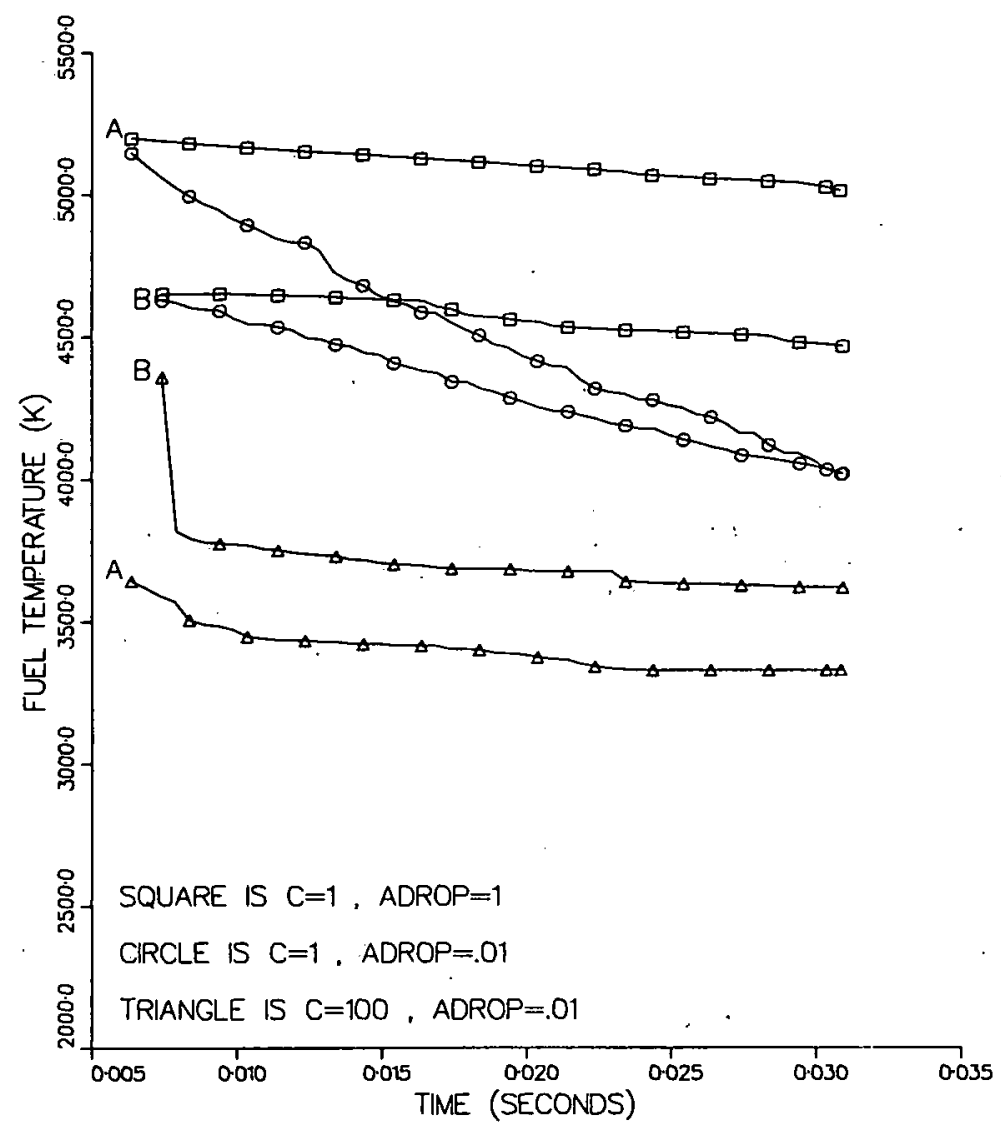

Fig. 7

Heat Transfer Effects on Fuel Peak Temperature. ANL Neg. No. 116-76-120.

Figure 9 shows how fuel to steel heat transfer can serve to reduce the available system work energy even by the time the core bubble reaches the blanket. For the calculations shown in this figure, the steel was initially at $1000^{\circ} \mathrm{K}$. No work was generated from the steel in these calculations, even when all the energy was assumed to go into clad and wire wrap steel, ignoring can wall steel. Parametric variation of initial steel temperature has indicated that when the initial steel temperature is higher, additional work energy can be obtained from the steel, with the breakeven point being somewhere around $2500^{\circ} \mathrm{K}$. for an initial steel temperature. Furthermore, the influence of can wall steel as an energy sink serves to 1 ower the work energy.

These studies indicate the need for further examination of the heat transfer between fuel, steel and coolant following a prompt burst. To date, damage estimates made with REXCO simply use a P-V relationship for the core bubble as a source to drive the sodium to impact. Furthermore, that $\mathrm{P}-\mathrm{V}$ relationship is obtained by examination of the available work energy in fuel alone at the end of the prompt burst. Our studies indicate that such a P-V curve may be significantly in error, even when the bubble is fairly small, due to energy. transfer among the core materials. The time scale for bubble growth appears to be long enough for fuel to steel and to coolant (in the LOF driven TOP) to be able to play a major role. A paper on this effect has been accepted 


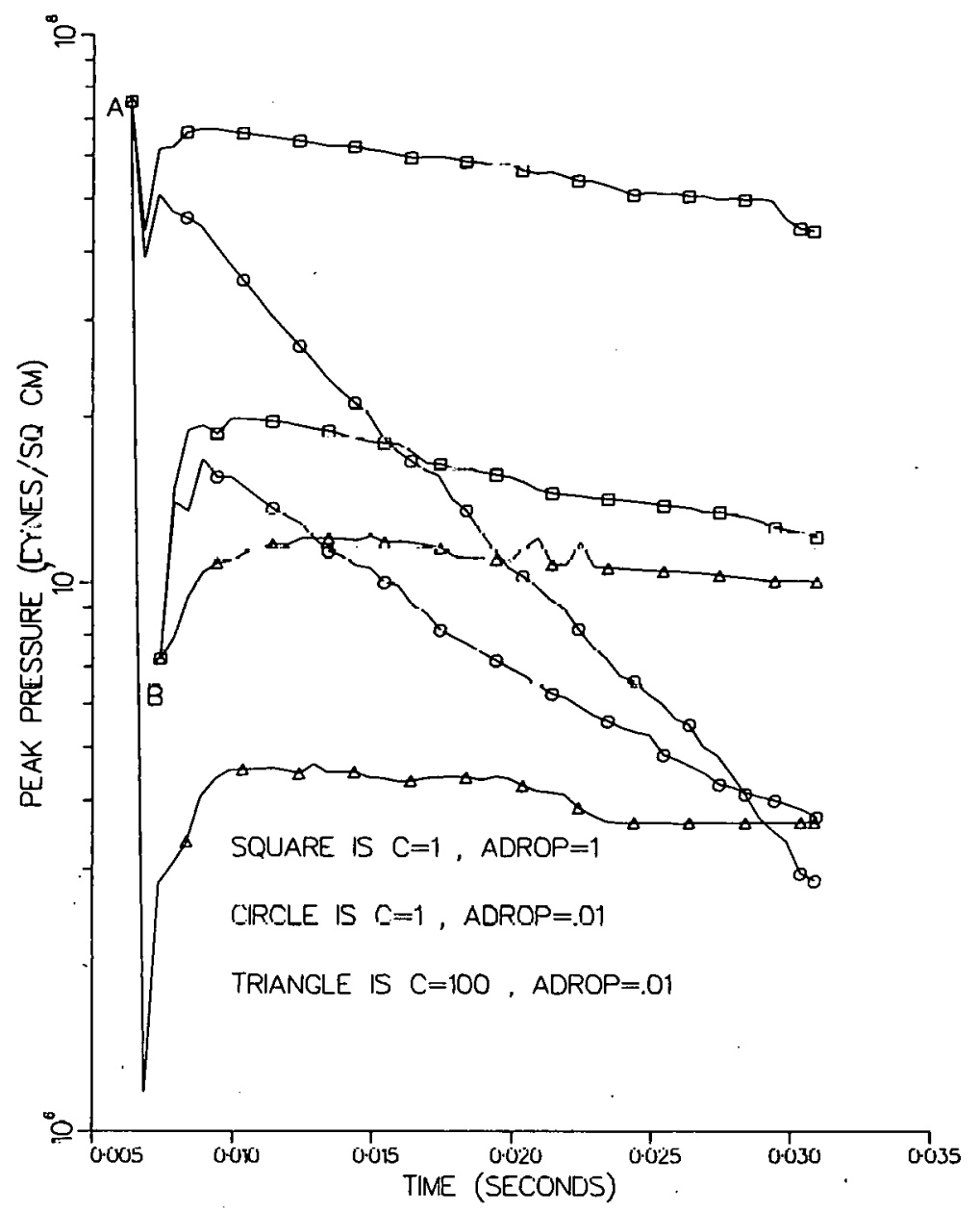

Fig. 8. Heat Transfer Effects on Peak Pressure. ANL Neg. No. $116-76-121$. 


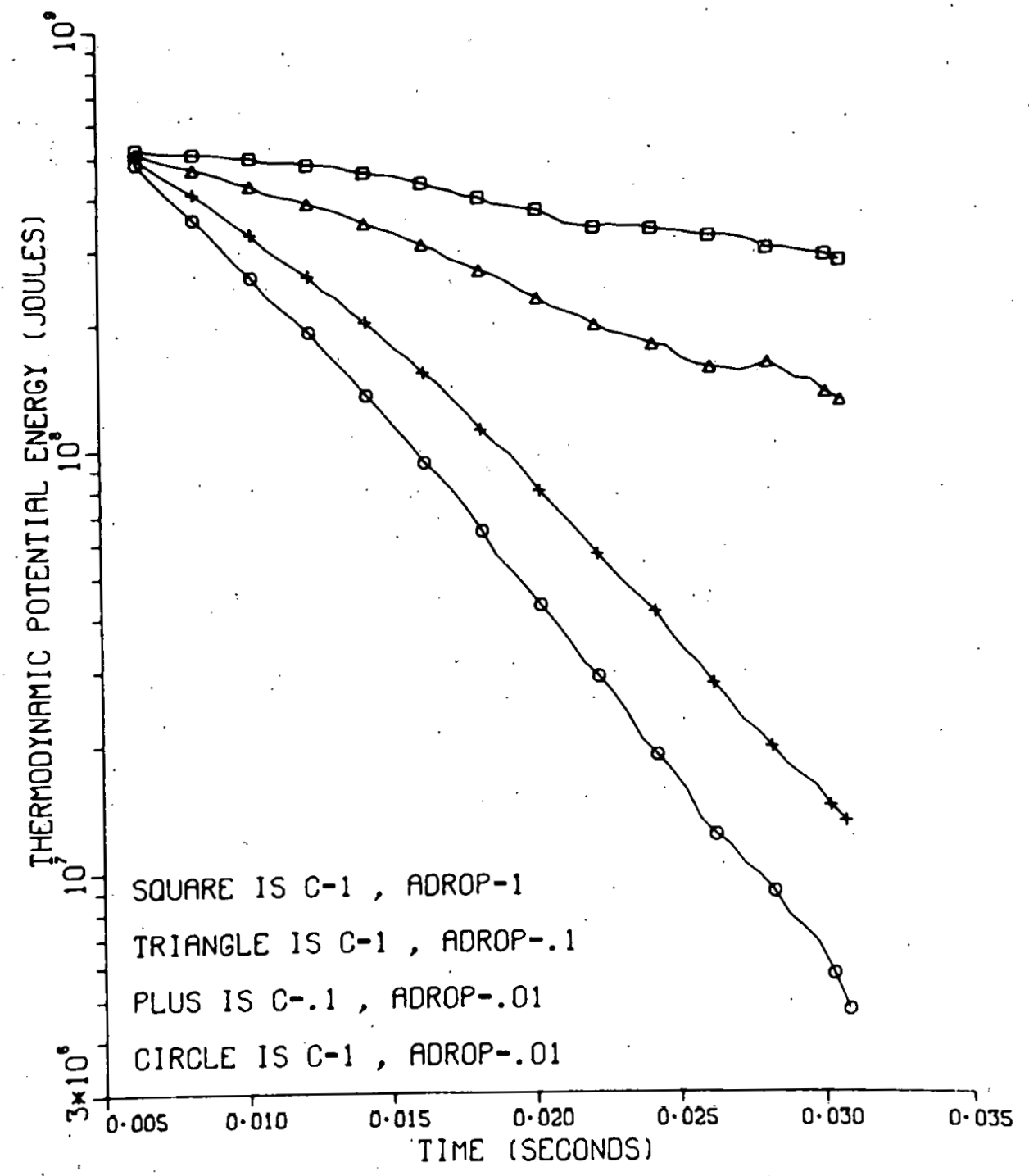

Fig. 9. Heat Transfer Effect on Work Potential. ANL Neg. No. 116-76-123. 
for publication at the Winter ASME meeting, and some information will also be presented at the October, 1976 Fast Reactor Safety meeting in Chicago.

4. Development of EPIC (P. A. Pizzica and P. B. Abramson)

Much of the present quarter was spent refining the EPIC fuelcoolant interaction code introducing such features as a more precise tracking of the liquid sodium slug interfaces, debugging minor problems, writing an input processor, adding auxiliary editing, and breaking up the code into modules to facilitate code development and debugging. The details are unimportant, but the effort was necessary.

The multi-node failure option which will allow EPIC to treat long clad failures is working both for the case of a length fixed in time (a rip up to $25 \mathrm{~cm}$ long was treated) and for a rip whose length increased with time (one case increased the rip by $10 \mathrm{~cm}$ after a couple of $\mathrm{msec}$, and then by another $10 \mathrm{~cm}$ after a few more $\mathrm{msec}$ ).

The case of ejecting fuel into a partially voided coolant channel is working and stable ( 40 and $60 \%$ void fractions were used). Also, a multiplenode failure into the partially voided channel was successfully run. Both of these options are now undergoing checkout and comparison. When more cases have been run, a summary of the results will be presented.

Also, we intend to run a series of cases, varying the most significant input parameters such as failure location, void fraction in channel, fuel temperature, etc., in order to compare EPIC with PLUTO1. We will also use all of EPIC's features in many different cases in order to test it thoroughly before using it for production calculations.

\section{COORDINATION OF RSR SAFETY RESEARCH}

P. Abramson and $H$. Hummel attended an RSR meeting on. SIMMER in Germantown on April 11 and a code validation meeting on April 12 in Germantown. As a result of the latter meeting, Abramson has now had two rounds of contacts with NRC ARSR consultants regarding experimental validation of SIMMER, HAARM and SSC. At this point we have received preliminary suggest-ions from each organization regarding their own potential contributions and are now awaiting the assessment of each reply by the other organizations. We shall attempt to have a preliminary plan on validation of SIMMER and HAARM ready by the end of calendar year 1976. Furthermore, as a result of the initial meeting, areas of strong mutual benefit have been identified between the HAARM experimental effort and the SIMMER analysis, and a cooperative effort has begun.

P. Abramson v1sited A.I. on April 22 to meet with R. T. Lancet and H. Morewitz to discuss recriticality and some fuel/steel interaction experiments being performed at A.I.

P. Abramson visited V. J. Dhir at UCLA on April 23 to discuss the UCLA experiments on crust formation (applied to fuel/steel pools) and to discuss debris bed experiments. 
P. Abramson visited LASL on April 25 to discuss SIMMER validation analysis of transition phase, and coordination with Sandia, and visited Sandia on Apri1 27. As a result of these meetings, several analysts from LASL visited Sandia to discuss the experimental capabilities, and a return visit is planned.

P. Abramson attended a PAHR review group on May 10 as a consultant to NRC (R. Wright), and submitted a critique of the meeting. H. Hummel, $P$. Abramson and P. Pizzica made presentations to the British delegation on June 24 at ANL.

\section{EVALUATION OF PROGRESS IN REACTOR SAFETY RESEARCH}

Papers published in Transactions of American Nuclear Society, 23:

"A Numerical Hydrodynamics Treatment of Fuel/Steel Pools with Density Variations from Nearly Pure Vapor to Incompressible Liquid."

P. B. Abramson, p. 192.

"The Importance of Fuel to Steel Heat Transfer in Neutronic and Work Energy Release in HCDA Calculations for LMFBRs."

P. B. Abramson, p. 327.

"Power and Reactivity Distribution in the Clinch River Breeder Reactor at the Beginning-of-Life (BOL)."

Kalimullah and H. H. Hummel, p. 570.

\section{MONTE CARLO ANALYSIS AND CRITICALS PROGRAM PLANNING FOR SAFETY-RELATED CRITICALS}

(A2018)

\section{MONTE CARLO ANALYSIS OF SAFETY-RELATED CRITICALS}

As previously reported, the Monte Carlo eigenvalue for an $R-Z$ model of the reference core agreed well with a corresponding diffusion theory eigenvalue. On the other hand, the Monte Carlo and diffusion theory eigenvalues disagreed by $1 \%$ for the step 5 damaged core. Computed eigenvalues are summarized in Table IV.

It is probably not surprising that Monte Carlo and diffusion theory eigenvalues disagree from the damaged core; it is surprising, however, that TWOTRAN disagrees so sharply with Monte Carlo and diffusion calculations for the reference core.

In order to make sure that the cross sections in TWOTRAN and DIF2D were consistent, infinite medium eigenvalues (i.e., $k$ 's) were computed for both the core and blanket materials, using both codes, with the core cross sections 
TABLE IV

\begin{tabular}{llc}
\hline & \multicolumn{2}{c}{ Computed Eigenvalues } \\
& Reference Core & Damaged Core (Step 5) \\
& 1.000 & 1.000 \\
Diff. Theory & $0.998 \pm 0.002^{\mathrm{a}}$ & $1.013 \pm 0.002^{\mathrm{a}}$ \\
VIM & 1.010 & Not yet available \\
TWOTRAN & & .
\end{tabular}

Confidence interval is standard deviation

as in the original $\mathrm{R}-\mathrm{Z}$ calculations. It was found that TWOTRAN and DIF2D $\mathrm{k}_{\infty}$ 's were essentially identical. Further, after a good deal of visual checking of data sets, no cross section discrepancies have been found.

Turther checlcing computatione have bean seen in spherical. genmetry, pressuring the $\mathrm{R}-\mathrm{Z}$ core volume. Computed eigenvalues in this geometry are listed in Table $\mathrm{V}$.

TABLE V

\begin{tabular}{ll}
\hline \multicolumn{1}{l}{ Computed Eigenvalues for 1-D Spluerleal Model. } \\
Diff. Theory & 1.0040 \\
ANISN & 1.0135 \\
VIM & $1.013 \% 0.002^{\mathrm{a}}(100,000$ histories) \\
\hline${ }^{\mathrm{a} C o n f i d e n c e ~ i n t e r v a l ~ i . s ~ s t a n d a r d ~ d e v i a t i o n ~}$
\end{tabular}

It will be noted that in the spherical model, one finds, again that the multigroup tránsport (i.e., AÑISN) eigenvalue is about $1 \%$ higher than the multigroup diffusion eigenvalue. This is actually, perfectly plausible in view of the very high leakage trom the core, a core with $k_{\infty}=1.539$. Since TWOTRAN and ANISN results show the same behavior, there is no reason to suspect any error in the TWOTRAN computation.

At this point we see two possible explanations for the VIM-'IWO'IRAN discrepancy in the reference core. First, it is possible that the VIM calculation, in spite of appearances, has not yet converged. Secondly, it may be that there are in the corners of the $\mathrm{R}-\mathrm{Z}$ core, spectrum effects which are not adequately modelled in 27 groups. Both possibilities are being investigated. In either case the original VIM-DIF2D agreement would be fortuitous.

\section{PLANNING OF DEMO SAFETY RELATED EXPERIMENTS}

This quarterly report includes a status report on the development of the program plan for the safety related critical experiments. The initial drafts of the planned sequence of critical assembly core configurations and the related critical assembly measurements are included in Tables VI and VII. 
TABLE V'I. Sequence of Crltical Assembly Core Configurations for Safety-Related Critical Experiments

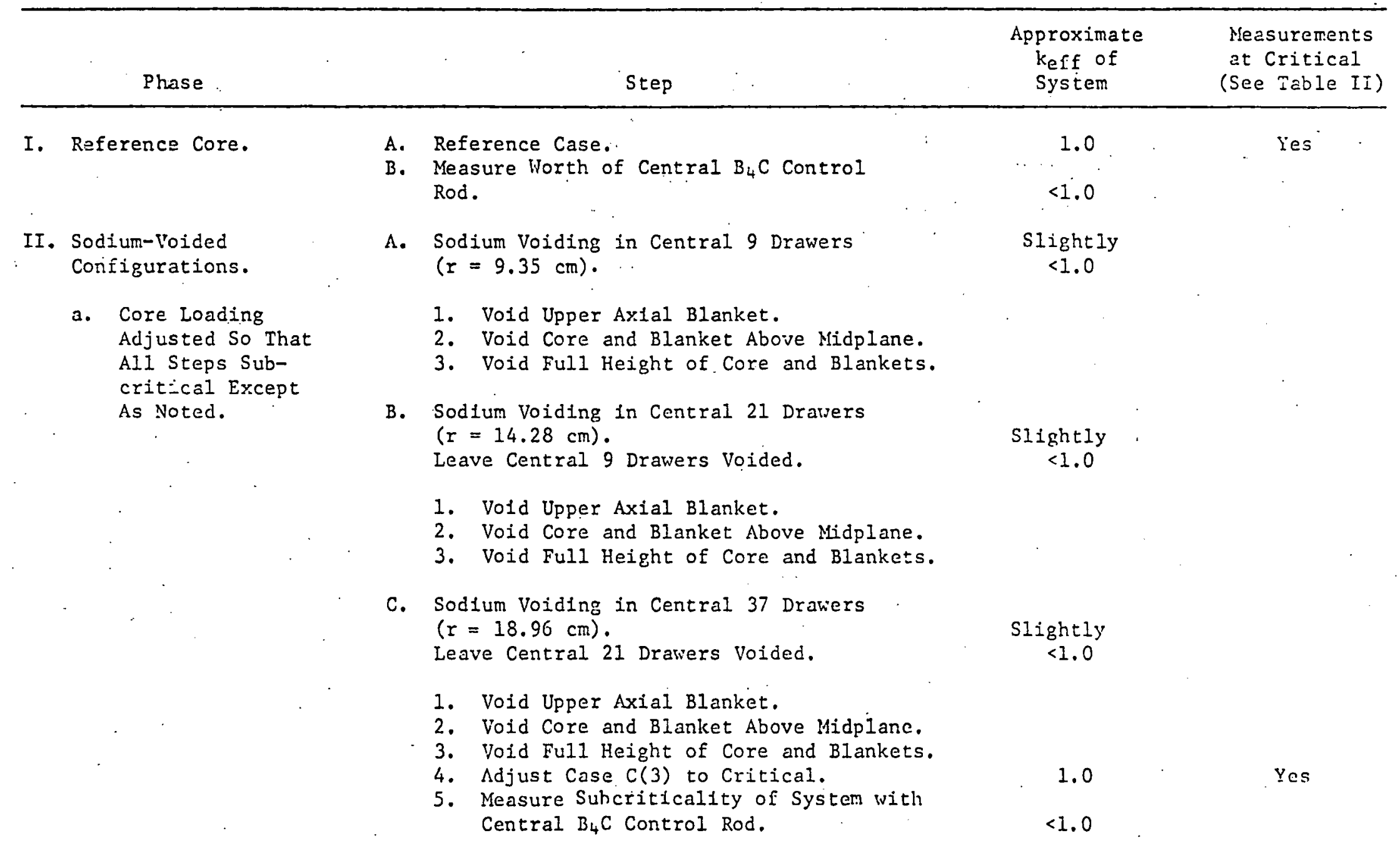


TABLE VI. (Contd.)

\begin{tabular}{ccc} 
& & Approximate \\
keff of & Measurements \\
at Critical & System & (See Table II) \\
\hline
\end{tabular}

III. Fue:1-Slump-Out

Configurations.

a. All Heasurements

Mede With Central

37 Drawers

Vie-Voiced.

b. Core Loacing Adjusted jo That All Steps Subcritical Except As Noted.
A. FueI slump Out in Central 9 Drawers. Al1 Fuel in Eegion $Z=0$ to $Z=\mathrm{H} / 2$

Slumps in Region for $\mathrm{H} / 2$ to $\mathrm{H}$, where $\mathrm{H}$ is the Half Height of Core and $z=0$ is at the Jore Nidplane.

1. Slunp Upper Half of Core.

2. Slump Over Full Core He-ght.

$<1.0$

$<1.0$

B. Fuel Slump Out in Central 2: Drawers. Le:ve Central 9 Drawers Slunped.

1. Slump Up?er Half of Core.

2. Sllmp Over Full Core Height.

$<1.0$

$<1.0$

C. Fuel Slump 0:at in Central 37 Drawers. Leave Central 21 Drawers SI-umped.

1. S:ump Upper Half of Core.

2. Siump Over Full Core Height.

3. Ad-ust Case $C(2)$ to Critical.

4. Measure Subcritlcality of System With Central $\mathrm{B}_{4} \mathrm{C}$ Control Rod.

5. Heasure Sujortticallty of System Wi-h Layer of $\mathrm{B}_{4} \mathrm{C}$ on Top of Laver Fuel Slump Region.

6. Measure Subcriticality of Systen Wi:h Layer of $B_{4} C$ on TCp of Upper Fidel Sllimp Region.
$<1.0$

$<1.0$

1.0

$<1.0$

$<1.0$

$<1.0$ 
TABLE VI. (Contd.)

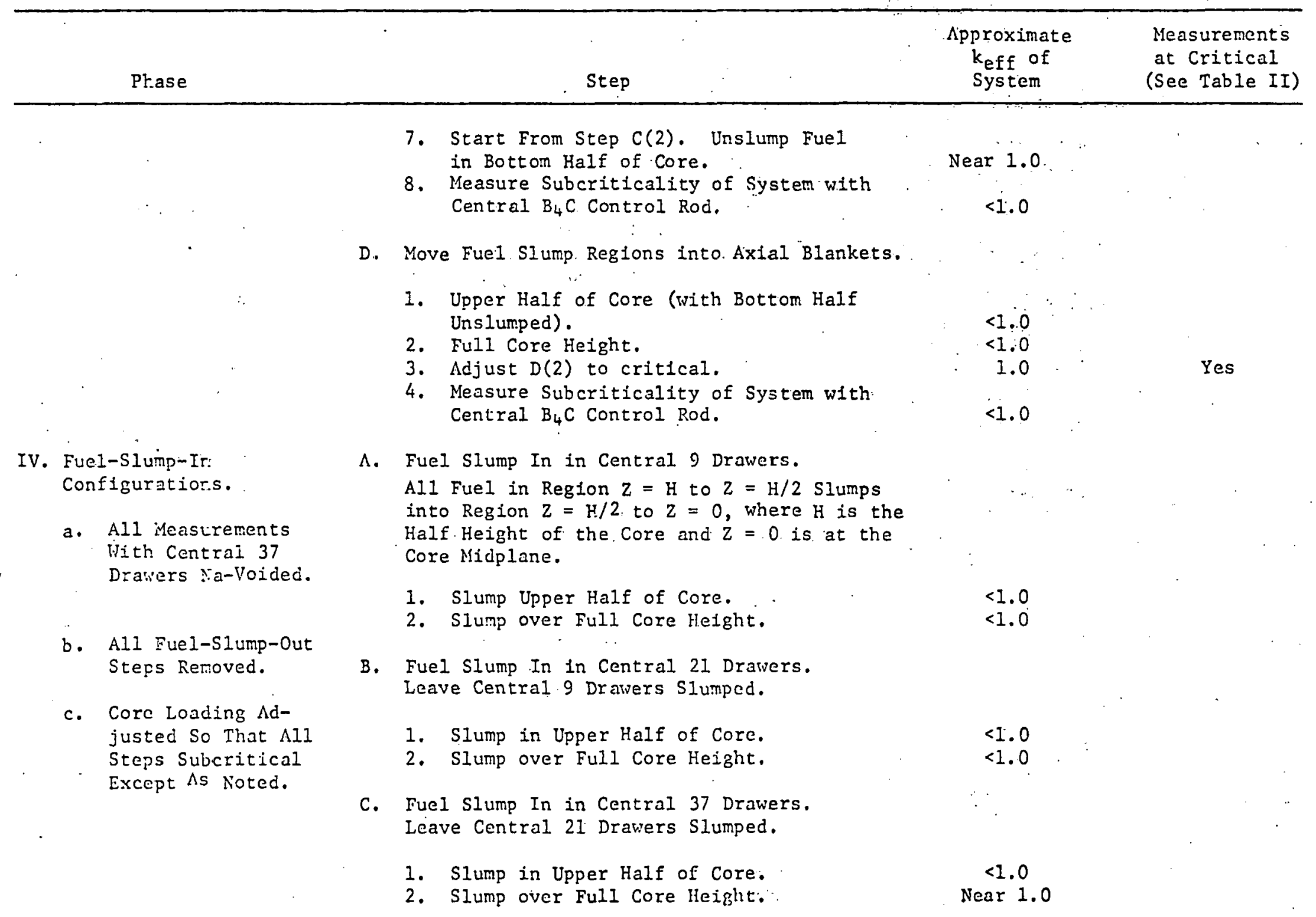


TABLE VI. (Contd.)

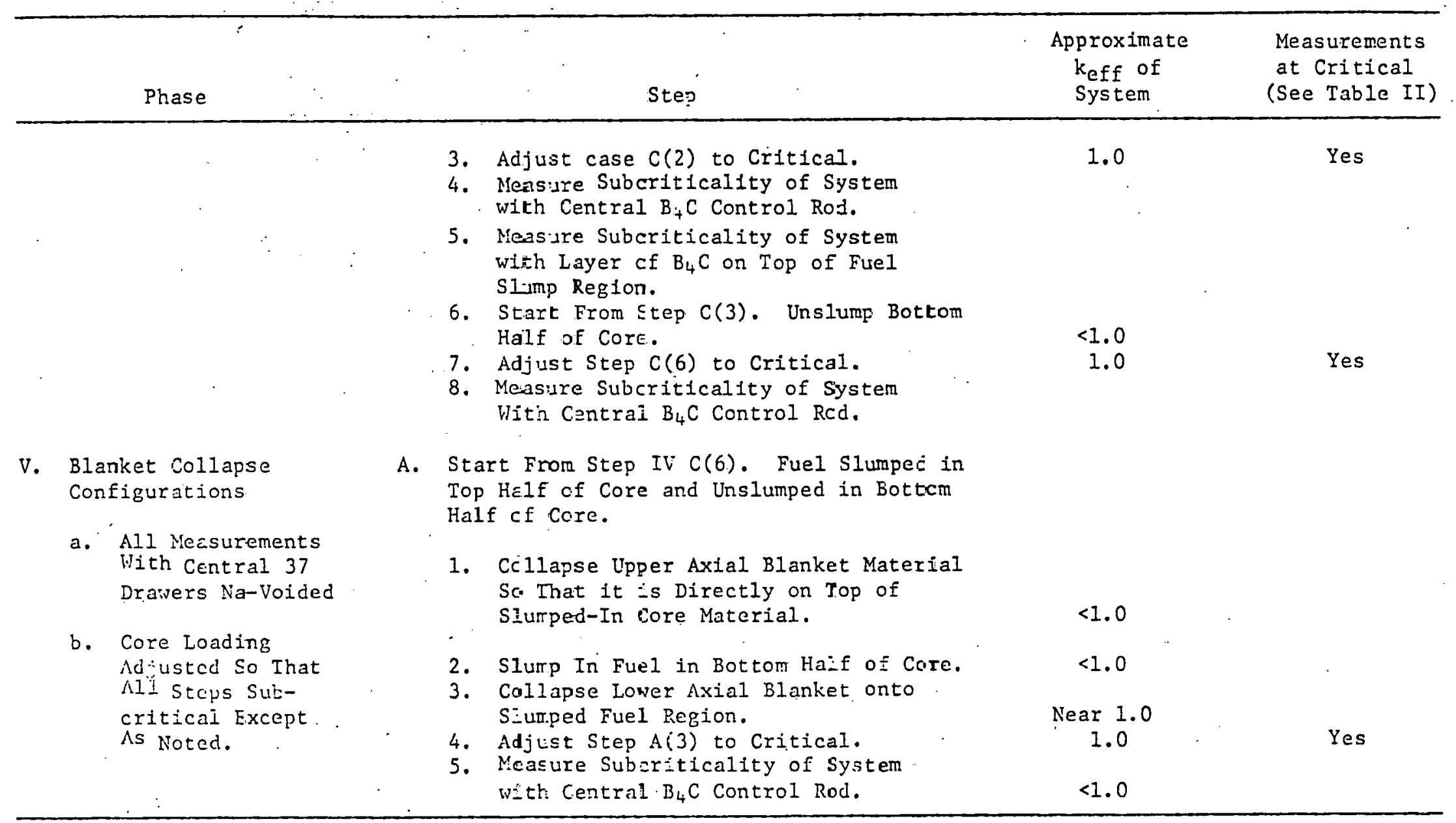


TABLE VII. Outline of Measurements for Safety-Related Critical Experiments

\begin{tabular}{|c|c|c|c|c|c|c|c|c|c|c|c|c|}
\hline $\begin{array}{l}\text { Phase/Step } \\
\text { (See Table I) }\end{array}$ & $k_{\text {eff }}$ & Spe & ctrum & $\beta_{\text {eff }}$ & $\begin{array}{r}\text { Reaction } \\
\text { Profi }\end{array}$ & $\begin{array}{l}\text { Rate } \\
\text { les }\end{array}$ & $\begin{array}{c}\text { Material } \\
\text { Worths }\end{array}$ & & $\therefore$ & Doppler & Coeffici & ient \\
\hline $\begin{array}{l}\text { I A } \\
\text { (Ref. Core) }\end{array}$ & $\checkmark$ & Core & Center & $\checkmark$ & Axial and & Radial & $\begin{array}{l}\text { Fuel, Structure; } \\
\text { Coolant - Axial } \\
\text { Radial Profiles }\end{array}$ & $\begin{array}{l}\text { Contr } \\
\text { and }\end{array}$ & rol, & $\begin{array}{l}: \\
\vdots\end{array}$ & e Center & $\cdots$ \\
\hline $\begin{array}{l}\text { II C (4) } \\
\text { (Na-Void) }\end{array}$ & $\checkmark$ & Coze & Center & $\checkmark$ & Axlal and & Radial & Axial Profiles & & & Core & e Center & \\
\hline $\begin{array}{l}\text { III C (3) } \\
\text { (Fuel-S lump-Dut, 1) }\end{array}$ & $\checkmark$ & & & & Axial and & Radial & Axial Profiles & & , & Fuel & 1 Region & \\
\hline $\begin{array}{l}\text { III D (3) } \\
\text { (Fue1-S Iump-Dut, 2) }\end{array}$ & $\checkmark$ & & & & Axial & & Axial Profiles & ' & . & & & \\
\hline $\begin{array}{l}\text { IV C (3) } \\
\text { (Fuel-S lump-In, 1) }\end{array}$ & $\sqrt{ }$ & Core & Center & $\checkmark$ & Axial and & Radial & $\begin{array}{l}\text { Axial and Radial } \\
\text { Profiles. }\end{array}$ & & . & Core & e Center & \\
\hline $\begin{array}{l}\text { IV C (7) } \\
\text { (Fue 1-S lump-In, 2) }\end{array}$ & $\checkmark$ & & . & & Axial & & $\begin{array}{l}\text { Axial Profiles } \\
\therefore\end{array}$ & . & & & & \\
\hline $\begin{array}{l}V A(4) \\
\text { (Blanket Collapse) }\end{array}$ & $\checkmark$ & Core & Center & & Nxial and & Radial & Axial profiles & . & . & Core & e Center & \\
\hline
\end{tabular}


The program, as presented in $\mathrm{Tab} l \mathrm{e} \mathrm{VI}$, is divided into the following five major phases.

I. Reference Core.

II. Sodium Voided Configurations.

III. Fuel-Slump-Out Configurations.

IV. Fuel-Slump-In Configurations.

V. Blanket Collapse Configurations (with Fue1-Slump-In).

In each phase the core perturbations have been accomplished in several axial and radial steps. In this manner data is provided to test both the magnitude of the perturbations and the trends of a perturbation as a function of other parameters. A central control rod has been included in several of the configurations in order to test the ability of the analysis to predict the perturbed case with control present.

The program of cores and measuremenls outlined in Tablea VI and VII is estimated to take from 12 to 15 months. Subsequent to the preparation of this program plan a new schedule was developed for ZPR-9: which considerably reduced the anticipated length of the salety-related criflcal experlutuls. The de velopment of a revised program plan aimed at a program of approximately 6 months duration is now necessary. 


\section{REFERENCES}

1. Physics of Reactor Safety; Quarterly Report, October-December, 1975, Argonne National Laboratory Report, ANL-76-13, pp. 2-4.

2. Clinch River Breeder Reactor Plant, Preliminary Safety Analysis Report; Project Management Corporation.

3. F. E. Dunn, et al., The SAS-2A LMFBR Accident Analysis Computer Code, Argonne National Laboratory Report, ANL-8138, (October 1974).

4. Physics of Reactor Safety, Quarterly Report, January-March 1976, Argonne National Laboratory Report, ANL-76-72, pp. 9-12.

5. B. Ganapol, C. Bowers, P. Abramson and P. Bleiwe1s, A Comparison of Three Disassembly Models for a $2000 \mathrm{MW}(e)$ Fast Breeder Reactor, Trans: Am. Nuc1. Soc. 22, p. 371, (1975). 